1963-64. Of these, 511 were undergraduate students in science and 348 in engineering; there were also 118 postgraduate students in science and 61 in engineering, with a further 13 and 8 , respectively, part-timo. Besidos tho departmental reviews the report includes a list of work published during the year.

\section{University College, London}

The annual roport of Univorsity Collogo, London, for 1963-64 (Pp. 109. London: University College, 1965), includes the report of the Chairman of the College Committee and the Provost, together with lists of publications during the year by members of College departments, lists of public locturos, university honours and awards, etc. Of the 4,124 students, 1,176 were postgraduate, 3,318 were from within the United Kingdom, and 364 from elsewhore within the British Commonwealth; 743 postgraduate students were from within the United Kingdom; 754 undergraduate and 432 postgraduate students were in science. For medical science the corresponding figures are 257 and 10; and for engineering, 290 and 121. A steoring committoo was set up during the yoar to examine urgently the problems presented by the federal structure of the University of London, which the College wishes to maintain. The postgraduato students increased by $8 \cdot \mathbf{5}$ per cent during the session, compared with 6.7 per cent in 1962-63, and in reforring to the expansion of the College, the report emphasizes that the main burden of advanced scientific work falls on 5 institutions, prominent among which is University College.

\section{International Commission on Zoological Nomenclature}

Notice is hereby given of the possible use by the Intornational Commission on Zoological Nomenclature of its plenary powers in connexion with the following cases, full details of which will be found in the Bulletin of Zoological Nomenclature (22, Part 1; April 5, 1965): (1) Designation of a neotype for Viverra zorilla Gmelin, 1788 (Mammalia). Z.N.(S.) 758. (2) Suppression of the generic name Pelta Quatrofages, 1844, or suppression of the family name RUNCINIDAE Gray, 1857 (Gastropoda). $Z . N .(S)$.580 . (3) Suppression of the generic names Acanthochila Mørch, 1868, and Echinochila Morch, 1869 (Gastropoda). Z.N.(S.) 582. (4) Suppression of the specific namo Tipula nubeculosa Meigen, 1804 (Insecta, Diptera). Z.N.(S.) 895. (5) Suppression of the generic name Faviphyllum Hall, 1852, and the specific name Faviphyllum rugosum Hall, 1852 (Anthozoa). Z.N.(S.) 1662. (6) Designation of a type-species for Ornipholidotos Bethune Baker, 1914 (Insecta, Lepidoptera). Z.N.(S.) 1663. (7) Suppression of the generic name Colaceutes Hartmann, 1856 (Crustacea, Copepoda). Z.N.(S.) 1664. (8) Designation of a type-species for Limacia Müller, 1781 (Gastropoda). Z.N.(S.) 1665. (9) Suppression of the generic name Eretmia Gosse, 1886, and the specific names Eretmia pentathrix Gosse, 1886, and Eretmia trithrix Gosse, 1886 (? Rotatoria). Z.N.(S.) 1666. (10) Designation of type-species for the following genera of Insecta, Lepidoptera: Ypthima Hübner, 1818 (Z.N.(S.) 1672); Napaea Hübner [1819] (Z.N.(S.) 1673); Iaspis Kayc, 1904 (Z.N.(S.) 1674); Pithcops Horsfield [1828] (Z.N.(S.) 1675); Arisoe Huibner [1819] (Z.N.(S.) 1676); Phrissura Butler, 1870 (Z.N.(S.) 1677); Adopaeoides Godman [1900] (Z.N.(S.) 1678); Artines Godman [1901] (Z.N.(S.) 1679); Gegenes Hübner [1819] (Z.N.(S.) 1680); Halpe Moore, 1878 (Z.N.(S.) ]681); Papias Godman [1900] (Z.N.(S.) 1682); Phanis Godman [1900] (Z.N.(S.) 1683); Telicota Moore [1881] (Z.N.(S.) 1684); Zenis Godman [1900] (Z.N.(S.) 1685). Any zoologist who wishes to comment on any of the foregoing cases should do so in writing to the Secretary, International Commission on Zoological Nomenclature, c/o British Museum (Natural History), Cromwell Road, London, S.W.7, before Octobor 5 .

\section{Announcements}

UNDER the Statute of the Royal Society of London, which provides for the election of persons who either have rendered conspicuous servico to the cause of science or are such that their election would be of signal benefit to the Society, Sir Robert Menzies has been elected a Fellow of the Royal Society.

Prof. Helen K. Porter has been elected chairman of the Committee of the Biochemical Society, and Sir John Gaddum has been elected an honorary member of the Society.

AN international summer school on "The Cerebellum" will be held at the Netherlands Central Institute for Brain Research, Amsterdam, during July 5-9. Further information can be obtained from Dr. J. P. Schadé, Central Institute for Brain Research, Ijdijk 28, Amsterdam (Havens-Oost).

AN international symposium on "Applied Microscopy" will be held in the University of Sheffield during July 6-9. In addition to general sessions, there will be special meetings dovoted to metallurgical microscopy, dusts, particle sizing and counting and fibre microscopy. Furthor information can be obtained from Prof. R. Barer, Depart. ment of Human Biology and Anatomy, University of Sheffield, Western Bank, Sheffield 10.

A sxmposium on "Molecular Relaxation Processes", arranged by the Chemical Society, will be held at the Edward Davies Chemical Laboratory, Aberystwyth, during July 7-9. The programme will include discussions on: dielectrics; ultrasonics; nuclear magnetic resonance; electron spin resonance. Further information can be obtained from the General Secretary, the Chemical Society, Burlington House, London, W.1.

A symposium on "Combustion Processes in the Spark Ignition Engine" will be held at the Advanced School of Automobile Engineering, Cranfield, during July 9-10. Further information can be obtained from Mr. D. Hodgetts, Advanced School of Automobile Engineering, Cranfield, Bedford.

THE twelfth International Spectroscopy Colloquium, organized under the auspices of the British Spectroscopists Co-ordinating Committee in collaboration with the Institute of Physics and the Physical Society, will be held in the University of Exeter during July 12-17. Further information can be obtained from Mrs. C. E. Arregger, 1 Lowther Gardens, Prince Consort Road, London, S.W.7.

The tenth Intermational Congress of Pure and Applied Chemistry, organized by the Academy of Sciences of the U.S.S.R., will be held in Moscow during July 12-18. Further information can be obtained from the Secretariat of the Congress, Institute of Chemical Physics, Academy of Sciences of the U.S.S.R., Vorobyevskoye chaussee 2b, Moscow V-334.

A JorNT meeting of the Challenger Society and representatives from the Marine Laboratories (Development Commissioners' Scheme) will be held at tho Fisheries Experiment Station, Castle Bank, Conway, during July 14-15. Further information can be obtained from R. I. Currie, National Institute of Oceanography, Wormley, Godalming, Surrey.

A sUMmer programme in "Thermodynamics" will be held at the Massachusetts Institute of Technology during July 19-30. The programme, which will be conducted as a workshop, will concentrate on the fundamental concepts of work, the laws of thermodynamics, temperature, heat, energy, entropy, availability, elosed and open systems and equilibrium. Further information can be obtained from the Summor Sossions Office, Massachusetts Institute of Technology, Building $E_{1} 19-356$, Cambridge, Massachusetts. 